\title{
Water Richness Zoning and Evaluation of the Coal Seam Roof Aquifer Based on AHP and Multisource Geological Information Fusion
}

\author{
Ke Zhou \\ Hydrogeology Bureau, China National Administration of Coal Geology, Handan 056004, China \\ Correspondence should be addressed to Ke Zhou; zhoukevvv@163.com
}

Received 14 April 2021; Accepted 29 July 2021; Published 29 October 2021

Academic Editor: Stefano Lo Russo

Copyright @ $2021 \mathrm{Ke}$ Zhou. This is an open access article distributed under the Creative Commons Attribution License, which permits unrestricted use, distribution, and reproduction in any medium, provided the original work is properly cited.

\begin{abstract}
Roof water disaster is one of the most serious disasters in the process of coal mine safety mining in China. The thickness of modern comprehensive mechanized coal mining is large, which has a great impact on the roof aquifer, and the threat degree of water disaster is also increasing. Therefore, the evaluation of the water richness of the roof aquifer is an important work for coal mine water prevention and control. In order to systematically evaluate the water-rich property of an aquifer in a coal seam roof, this paper couples multisource geological information based on an analytic hierarchy process (AHP). The characteristics of the roof aquifer, hydrogeology, and structure are determined to be the main control factors of $\mathrm{K}_{2}$ limestone water richness evaluation. Under the main control factors, seven independent water richness evaluation indexes, including aquifer depth, aquifer thickness, borehole water level, borehole water consumption, faults, folds, and collapse columns, are divided, and a normalized water richness coupling evaluation model is constructed, which realizes the zoning and evaluation of a water-rich aquifer in a coal seam roof.
\end{abstract}

\section{Introduction}

Mine water disaster is a major threat to coal mine safety production, among which water inrush from the roof aquifer is one of the main types of coal mine water disaster. With the popularization of modern comprehensive mechanized coal mining, in order to make full use of coal resources to the maximum extent, the mining thickness of coal seam increases, which leads to the increase in the influence range of the caving zone and water-conducting fracture zone of the coal seam roof, the damage to the roof aquifer increases, and the threat degree of water disaster increases accordingly. The water richness of the aquifer is one of the important influencing factors of mine roof water disaster intensity [14]. Before coal mining, it can systematically and accurately evaluate the water richness of the aquifer and predict the water inrush threat of the aquifer during mining, which will accurately guide the coal mine water prevention and control work and reduce the probability of roof water inrush and water damage.
Generally, the strength of water richness of the aquifer can be visually characterized by unit water inflow [5], but there are great differences in coal seam occurrence conditions and hydrogeological conditions in different mining areas, so it is obviously not comprehensive to rely solely on unit water inflow. The distribution law of water richness of the aquifer in the coal mine roof is controlled by the comprehensive influence of multiple geoscience factors, including the original stratum background factors, complex hydrogeology, tectonic geology, and other control mechanisms as well as linear and nonlinear characteristics. The evaluation of water richness of the aquifer is a systematic evaluation of multisource geological information factors and artificial mining effects [6-8]. Based on this, many scholars use various methods to evaluate the water richness of the aquifer. Wu et al. [9-11] put forward a GIS-based information fusion aquifer water richness evaluation method, which was named "water-rich index method", and realized the multiangle and all-round evaluation of water richness of the aquifer. Lv et al. [12] propose the "multitype four-double method" evaluation and 
prediction technology, which improved the accuracy and sensitivity of evaluation and overcome the deficiency of the empirical formula. Bu et al. [13] completed the water richness zoning of the roof by using an information fitting method and made fuzzy prediction on this basis. Qiu et al. [14] put forward a comprehensive grey correlation method, fuzzy Delphi analytic hierarchy process, and geophysical exploration-combined evaluation and prediction method of Ordovician limestone water richness. Han et al. [15] introduced a set pair analysis-variable fuzzy set coupling evaluation method to predict and evaluate the water richness of the coal seam roof aquifer and constructed the aquifer water richness evaluation model of the Zhiluo Formation aquifer based on the set pair analysis-variable fuzzy set coupling evaluation method. Hou et al. [16] aiming at the problem of water richness prediction of weathered bedrock established a Fisher discriminant analysis model of water richness of the aquifer type of the weathered bedrock aquifer by using the measured unit water inflow and index data of the borehole. Wei et al. [17] combined the improved entropy weight method and analytic hierarchy process by introducing the distance function, obtained the comprehensive weight of the main control factors of water inrush, and constructed the calculation model of the water inrush risk index. Xue [18] put forward the water richness index method based on fractal theory to evaluate aquifer water richness and gave the evaluation process. Compared with the traditional water richness evaluation method, this method reduces the number of structural description elements by $2 \sim 3$ items and solves the problem of reasonable and accurate evaluation and zoning of aquifer water richness under the condition of low hydrogeological exploration. Guo et al. [19] divided the water richness grade of this mining area into three grades by the FAHP method and ArcGIS as the platform, combined with the GRA grey correlation degree, and determined the threshold value of water richness classification objectively.

In this paper, through comprehensive analysis of multisource geological information such as aquifer thickness, borehole water level, borehole water consumption, faults, folds, and collapse columns of $\mathrm{K}_{2}$ limestone in the direct roof aquifer of the no. 15 coal in the lower group of the coal seam in a mine field, AHP is used to carry out multifactor coupling analysis, and a normalized evaluation model of water richness of the aquifer is established, finally realizing the zoning evaluation of water richness of the aquifer in the roof of the mine field.

\section{Overview of the Study Area}

The study area is located in the deep circulating runoff area of karst water in the Niangziguan spring area and is divided into six aquifer rock groups from bottom to top, which are the limestone karst fissure aquifer group of the middle Ordovician Shangmajiagou Formation, limestone karst fissure aquifer group of the middle Ordovician Fengfeng Formation, karst and sandstone fissure aquifer group of the upper Carboniferous Taiyuan Formation, sandstone fissure aquifer group of the lower Permian Shanxi Formation, sandstone fissure aquifer group of the Permian, and pore aquifer group of the Quaternary glutenite layer. Among them, the $\mathrm{K}_{2}$ limestone aquifer in the karst and sandstone fissure aquifer group of the Taiyuan Formation of the Upper Carboniferous System is the direct roof aquifer for mining no. 15 coal in the future mining field, which poses a great flood threat to the mining of no. 15 coal. According to statistics, $\mathrm{K}_{2}$ limestone water gushed during the construction of an inlet and return air shaft from 2009 to 2014, and the water gushed from different locations ranging from 5 to $102.30 \mathrm{~m}^{3} / \mathrm{h}$. From 2015 to $2020,10 \mathrm{~K}_{2}$ limestone water exploration holes were constructed, of which 3 holes had water gushing about $1 \mathrm{~m}^{3} / \mathrm{h}$ and the other water exploration holes had no water outflow. According to the actual exposure, it shows that the $\mathrm{K}_{2}$ limestone aquifer of the Taiyuan Formation in the mining field is characterized by uneven water richness and abnormal local water richness.

\section{Analysis of the Main Controlling Factors of Water Richness in the $K_{2}$ Limestone Karst Aquifer}

For the $\mathrm{K}_{2}$ limestone karst aquifer, the water richness of the limestone aquifer is largely affected by the development of karst space in limestone. Therefore, the factors that affect the karst development degree are also the factors that determine the water richness of the karst aquifer. In this paper, based on the factors affecting karst development and combined with the specific conditions of the study area, the aquifer characteristics, hydrogeological characteristics, and structural characteristics are selected as the main control factors to study the water richness of the karst aquifer.

3.1. Aquifer Characteristics. $\mathrm{K}_{2}$ limestone water mainly occurs in karst space, so the properties of $\mathrm{K}_{2}$ limestone and the development characteristics of karst fissures will greatly affect the aquifer characteristics. First of all, its nature is the thickness of the limestone aquifer. Under normal circumstances, a thicker aquifer has the potential to store more groundwater, and under the condition of satisfying karst development, large dissolution caves will be formed. Another characteristic of the limestone aquifer is the buried depth of limestone. The greater the buried depth, the slower the groundwater circulation, the smaller the dissolution power provided by groundwater movement, and the worse the dissolution degree. When the buried depth of $\mathrm{K}_{2}$ limestone is greater, its water storage space is compressed under the action of the self-weight stress of overlying strata, which reduces the water richness degree of limestone.

3.2. Hydrogeological Characteristics. Hydrogeological characteristics are an important factor affecting limestone water richness. Hydrogeological parameters, such as permeability coefficient, directly reflect $\mathrm{K}_{2}$ limestone water abundance, while groundwater level reflects runoff conditions in the mining field. Another measurable indicator is water consumption of drilling holes, which can well reflect the location and degree of karst fracture development. The greater water consumption of drilling holes indicates fracture development in this horizon. Under the condition of karst development, 
there are abundant dissolution fractures in this layer, which makes the water richness degree of this layer good.

3.3. Structure Characteristics. Faults, folds, karst collapse columns, and other structures are mainly developed in the mine field. The structural development degree greatly affects the stability of $\mathrm{K}_{2}$ limestone development, and it is easy to form a flow channel for groundwater in limestone. Under the condition of satisfying karst development, a larger karst water storage space will be formed.

Karst development is the result of multiple factors such as lithology, structure, hydrogeological conditions, and landform, but in fact, topography and hydrogeological characteristics in karst areas are controlled by structure, lithology is the material basis, hydrology and landform are important conditions for karst formation, and structure is the main controlling factor for karst development, which is described as follows:

(1) Faults provide the migration channel of groundwater, and the rocks in the fault zone are generally broken and have good water conductivity under the condition of loose cementation, and the development degree of faults is positively correlated with the water abundance of $\mathrm{K}_{2}$ limestone

(2) The rock mass in the collapse column is broken, the stress is released, and the in situ stress redistribution causes the local stress concentration around the collapse column, which leads to the development of fracture zones with a certain width around and above the collapse column. The thickness of the effective water-resisting layer is reduced, which generally leads to multiple aquifers. In addition, the crushing strength of the column is reduced, and it is easy to shear under limestone water pressure and water infiltration. The pores and fissures formed by column breakage become the channels of groundwater seepage. On the whole, collapse column development and karst development promote each other

(3) The influence of the development degree of the fold structure on the karst development degree is mainly reflected in the fact that a large number of tensile joints are associated with the fold crankshaft and the turning end, which develop in the roof and floor strata of the coal seam, forming a good water storage space for the $\mathrm{K}_{2}$ limestone aquifer. And some fissures are also channels for groundwater storage and migration, which will form a large karst space under suitable conditions in the long process of geological evolution. In general, the fold structure promotes karst development

\section{Establishment of the Water Richness Evaluation Model}

Aquifer characteristics, hydrogeological characteristics, and structural characteristics are determined as the three main control factors to control $\mathrm{K}_{2}$ limestone water richness evalu- ation, and seven independent factors such as aquifer thickness, buried depth, borehole water level, borehole water consumption, faults, collapse columns, and folds are established under the three main control factors. Geoinformation thematic maps of independent factors are established, respectively, and geoinformation data are analyzed by spatial fusion based on the analytic hierarchy process [10].

4.1. Quantitative Expression Method of Each Factor. By analyzing drilling data of $\mathrm{K}_{2}$ limestone, the buried depth value of the $\mathrm{K}_{2}$ limestone roof, thickness value of $\mathrm{K}_{2}$ limestone, and initial water level value of the aquifer are counted. According to a simple hydrological chart, the maximum water consumption of the drilling hole in $\mathrm{K}_{2}$ limestone is counted and the degree of structural development is quantitatively evaluated by fractal dimension theory [20].

In this study, the study area is divided into 350 square units of $500 \mathrm{~m} \times 500 \mathrm{~m}$ (among which 117 grids have structures). Every $500 \mathrm{~m}$ long grid is subdivided into $250 \mathrm{~m}$, $125 \mathrm{~m}$, and $62.5 \mathrm{~m}$ square grids, and the number of grids passing through each level of the construction trace is counted one by one, so as to obtain the $N\left(r_{i}\right)$ values when $R=250 \mathrm{~m}$, $125 \mathrm{~m}$, and $62.5 \mathrm{~m}$, which are put into the $\lg N(r)-\lg r$ coordinate system to generate fitting straight lines, and their slopes can be calculated by the least square method.

$$
D\left|\frac{N \times \sum_{i=1}^{n} N\left(r_{i}\right) r_{i}-\sum_{i=1}^{n} N\left(r_{i}\right) \sum_{i=1}^{n} r_{i}}{n \sum_{i=1}^{n} r_{i}^{2}-\left(\sum_{i=1}^{n} r_{i}\right)^{2}}\right| .
$$

After calculating one by one, assign the absolute value of fractal dimension $D$ of all grids to the center point of the corresponding grid unit and then interpolate one by one to make the contour map of fractal dimension in the whole region.

4.2. Determination of Weights among Factors. In this study, an analytic hierarchy process was used to determine the weight value of each independent factor in the $\mathrm{K}_{2}$ limestone aquifer water richness evaluation model. Based on the basic principle of the analytic hierarchy process, firstly, the hierarchical structure analysis model is established, and the judgment matrix is constructed. Then, the importance of each influencing factor is scored by the expert scoring system, and then, the consistency test is carried out, and finally the weights among each influencing factor are obtained [21-23].

According to the analysis of multivariate information reflecting aquifer water abundance, it can be divided into three levels. The ultimate goal of this problem is to evaluate the water abundance of the $\mathrm{K}_{2}$ limestone aquifer, which is taken as the target layer (level A) of the model. Aquifer characteristics, hydrogeological characteristics, and structural characteristics reflect the water richness degree of the aquifer, but its influence mode needs to be reflected by specific factors related to it, which is the intermediate link to solve the problem. As the criterion layer (level B) of the model, each specific multivariate geoscience information constitutes the decisionmaking level (level C) of this model, and the required solution can be finally achieved by making decisions on the 


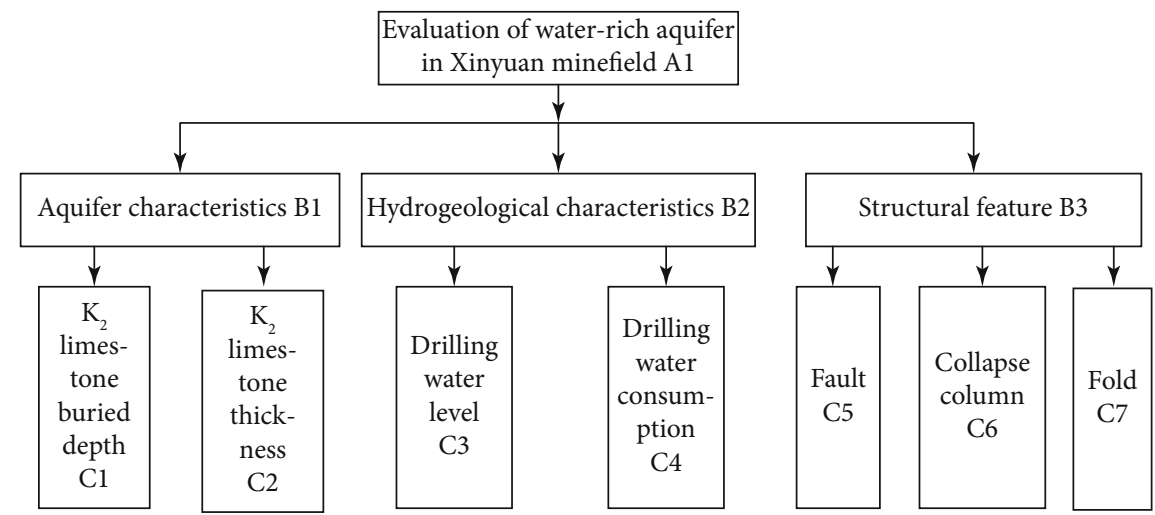

FIGURE 1: Hierarchical analysis structure model for water richness evaluation of the $\mathrm{K}_{2}$ limestone aquifer.

TABLE 1: Scale and meaning of judgment matrix.

\begin{tabular}{ll}
\hline Scale & Meaning \\
\hline 1 & Compared with the two factors, they have the same importance \\
5 & Compared with the two factors, the former is slightly more important than the latter \\
7 & Compared with the two factors, the former is obviously more important than the latter \\
9 & Compared with two factors, the former is extremely more important than the latter \\
$2,4,6,8$ & The intermediate value of the above adjacent judgments \\
Reciprocal & If the ratio of importance of factor $i$ to factor $j$ is $a_{i j}$, then the ratio of importance of factor $j$ to factor $i$ is $a_{j i}=1 / a_{i j}$
\end{tabular}

problems at this level. See Figure 1 for the analysis structure model.

4.2.1. Construct the Judgment Matrix. According to the analysis of the factors affecting water inrush in the Xinyuan Mine, using the method of "collecting experts to score," the opinions of field experts and researchers in universities and scientific research units are collected and consulted and their opinions are widely listened to. According to their personal experience and experience in field production practice and scientific research and specific methods to deal with problems, many factors affecting water inrush are scored. The scoring standard is to list the proposed factors affecting water inrush according to the scale method of 1-9 created by Saaty (the scale and meaning of the judgment matrix are shown in Table 1) [24] and invite domain experts to evaluate the relative importance of each factor according to the role of each factor in numerous water inrush accidents and their personal experience in production practice and scientific research. The quantitative score of each factor is given. According to the final cumulative score, the total scores of each factor are compared, and the expert evaluation set of each influencing factor is formed, thus constructing the judgment matrix of AHP evaluation of roof and floor water inrush risk.

4.2.2. Hierarchical Single Sorting and Consistency Check. According to the judgment matrix, the weights of single ordering of each layer are calculated as shown in Tables 2-5.

The above judgment matrix CR is less than 0.1 , which has satisfactory consistency and can pass the consistency test.
TABle 2: Judgment matrix $A \sim B i(i=1 \sim 3)$.

\begin{tabular}{cccccc}
\hline$A$ & $B 1$ & $B 2$ & $B 3$ & $W\left(\frac{A}{B}\right)$ & $\lambda_{\max }=3.002$ \\
$B 1$ & 1 & $1 / 2$ & $1 / 3$ & 0.166 & $\mathrm{CI}=0.001$ \\
$B 2$ & 2 & 1 & $3 / 5$ & 0.320 & $\mathrm{CR}=0.0017<0.1$ \\
$B 3$ & 3 & $5 / 3$ & 1 & 0.514 & \\
\hline
\end{tabular}

TABle 3: Judgment matrix $B 1 \sim C i(i=1 \sim 2)$.

\begin{tabular}{ccccc}
\hline$B 1$ & $C 1$ & $C 2$ & $W\left(\frac{B}{C}\right)$ & $\lambda_{\max }=2$ \\
$C 1$ & 1 & 2 & $2 / 3$ & $\mathrm{CI}=0$ \\
$C 2$ & $1 / 2$ & 1 & $1 / 3$ & $\mathrm{CR}=0<0.1$ \\
\hline
\end{tabular}

TABle 4: Judgment matrix $B 2 \sim C i(i=3 \sim 4)$.

\begin{tabular}{ccccc}
\hline$B 2$ & $C 3$ & $C 4$ & $W\left(\frac{B}{C}\right)$ & $\lambda_{\max }=2$ \\
$C 3$ & 1 & $1 / 4$ & $1 / 5$ & $\mathrm{CI}=0$ \\
$C 4$ & 4 & 1 & $4 / 5$ & \\
\hline
\end{tabular}

4.2.3. Hierarchical Total Sorting and Consistency Test. The general ranking of local academic information in aquifer water richness analysis is shown in Table 6, which shows the weight result of each index $C i$ in the index layer to target layer $A$ through $B i$ layer. The symbol $A / C i$ indicates that each 
TABLE 5: Judgment matrix $B 3 \sim C i(i=5 \sim 7)$.

\begin{tabular}{cccccc}
\hline B3 & C5 & C6 & $C 7$ & $W\left(\frac{B}{C}\right)$ & \\
$C 5$ & 1 & 3 & 2 & 0.548 & $\lambda_{\max }=3.018$ \\
CI $=0.009$ \\
$C 7$ & $1 / 3$ & 1 & 1 & 0.211 & $\mathrm{CR}=00016<0.1$ \\
\hline
\end{tabular}

TABLE 6: Hierarchical general ordering of local learning information in aquifer water richness analysis.

\begin{tabular}{lcccc}
\hline$A$ & $B 1$ & $B 2$ & $B 3$ & $\mathrm{WC}_{\text {总 }}$ \\
\hline$C 1$ & 0.166 & 0.320 & 0.514 & 0.111 \\
$C 2$ & 0.667 & & & 0.055 \\
$C 3$ & 0.333 & & & 0.064 \\
$C 4$ & & 0.200 & & 0.256 \\
$C 5$ & 0.800 & & 0.282 \\
$C 6$ & & 0.548 & 0.108 \\
$C 7$ & & & 0.211 & 0.124 \\
\hline
\end{tabular}

index $C i$ is relative to total target $A$, and $W A / C i$ is the weight of each index $C i$ to total target $A$.

Calculate and get the random consistency ratio of the total sorting of layer $C$ :

$$
\mathrm{CR} 2=\frac{\sum_{i=1}^{n} \mathrm{CI}_{2 i} W\left(A / B_{i}\right)}{\sum_{i=1}^{n} \mathrm{RI}_{2 i} W\left(A / B_{i}\right)}(n=1,2) .
$$

Therefore, $\mathrm{CR}<0.1$ has satisfactory consistency, and $W$ $\mathrm{A} / \mathrm{Ci}$ can be used as the final decision-making basis, so as to determine the weight value superimposed by multiple information in the study of water richness zoning of water-filled aquifers (Table 7).

4.3. Establishment of the Water Richness Evaluation Model. The water richness index is the sum of the superposition effects of various independent information in a certain area or a certain position, and it is a normalized measure of the water richness degree of the aquifer $[10,11]$.

In fact, the evaluation model of $\mathrm{K}_{2}$ limestone water richness of the aquifer is to establish a mathematical model to express the comprehensive influence degree of various factors. The calculated value of the model can reflect the water richness of the aquifer in a certain geographical position. The establishment of the preliminary model must be based on the analysis of geological conditions, water richness factors, and the contribution mechanism of each factor to water inrush.

The initial model of water richness index $\mathrm{CI}$ is introduced to evaluate the water richness of the aquifer. It can be expressed by the following model formula:

$$
\mathrm{CI}=\sum_{k=1}^{n} W_{k} \cdot f_{k}(x, y),
$$

where $\mathrm{CI}$ is the water richness index, $W_{k}$ is the weight of geoscience information, $f_{k}(x, y)$ is the normalized single information influence value function, $x, y$ is the geographical coordinate, and $n$ is the number of multivariate information. $f_{k}(x, y)$ is the normalized value of the $k$ th geoscience information value in the evaluation of the water-rich aquifer of the coal seam roof. The weight values of each influencing factor are $W_{1}=0.111, W_{2}=0.055, W_{3}=0.064, W_{4}=0.256$, $W_{5}=0.282, \quad W_{6}=0.108$, and $W_{7}=0.124$, respectively. Therefore, it can be concluded that the water richness evaluation model of the coal seam roof aquifer is

$$
\begin{aligned}
\mathrm{CI}= & \sum_{k=1}^{n} W_{k} \bullet f_{k}(x, y)=-0.111 \times f_{1}(x, y) \\
& +0.055 \times f_{2}(x, y)+0.064 \times f_{3}(x, y) \\
& +0.256 \times f_{4}(x, y)+0.282 \times f_{5}(x, y) \\
& +0.108 \times f_{6}(x, y)+0.124 \times f_{7}(x, y) .
\end{aligned}
$$

\section{Evaluation of Water Richness Zoning of the $\mathrm{K}_{2}$ Aquifer}

The determined structural fractal dimension data coordinates are cast into the normalized thematic map of aquifer characteristics and the normalized thematic map of hydrogeological characteristics, and the subitems of aquifer characteristic and hydrogeological characteristic evaluation are read out, respectively, and recorded in the structural fractal dimension value list. The normalized fractal dimension value constructed at that same coordinate point and the normalized values of aquifer characteristics and hydrogeological characteristics are multiplied by corresponding weight values and then added to obtain the comprehensive evaluation index table of water richness. Import the final data list into the analysis and drawing software, and get the comprehensive evaluation map of water richness.

\subsection{Single-Factor Thematic Map}

\subsubsection{Thematic Map of Aquifer Characteristics}

(1) Thematic Map of $K_{2}$ Aquifer Thickness. On the basis of fully collecting and sorting out the previous drilling data, the thickness and buried depth of limestone above $\mathrm{K}_{2}$ or $\mathrm{K}_{2}$ are counted, respectively, and the thematic map of $\mathrm{K}_{2}$ limestone aquifer thickness is drawn by using the powerful interpolation function of Surfer, which is a Kriging interpolation method (shown in Figure 2). It can be seen from Figure 2 that the thickness of the $\mathrm{K}_{2}$ limestone aquifer changes greatly and the thickness of the $\mathrm{K}_{2}$ limestone aquifer generally becomes thinner from northwest to southeast, and $\mathrm{K}_{2}$ limestone is missing locally. The thickness of $\mathrm{K}_{2}$ limestone is mostly distributed in 1-3 $\mathrm{m}$, and the thickness of limestone in some areas is more than $3 \mathrm{~m}$, among which the thickest limestone area is $12 \mathrm{~m}$.

(2) Thematic Map of $K_{2}$ Limestone Burial Depth. According to the data of $\mathrm{K}_{2}$ limestone exposed by drilling statistics, a thematic map of $\mathrm{K}_{2}$ limestone floor buried depth is drawn, 
TABLE 7: The weight of local learning information in aquifer water richness analysis.

\begin{tabular}{lccccccc}
\hline Richness & $\begin{array}{c}\text { Depth of } \\
\mathrm{K}_{2} \text { limestone }\end{array}$ & $\begin{array}{c}\text { Thickness of } \\
\mathrm{K}_{2} \text { limestone }\end{array}$ & $\begin{array}{c}\text { Water level of } \\
\mathrm{K}_{2} \text { limestone }\end{array}$ & $\begin{array}{c}\text { Drilling water } \\
\text { consumption }\end{array}$ & Fault density & $\begin{array}{c}\text { Collapse } \\
\text { column density }\end{array}$ & $\begin{array}{c}\text { Fold density } \\
\text { Weight }(\mathrm{Wi})\end{array}$ \\
\hline & 0.111 & 0.055 & 0.064 & 0.256 & 0.282 & 0.108 \\
\hline
\end{tabular}
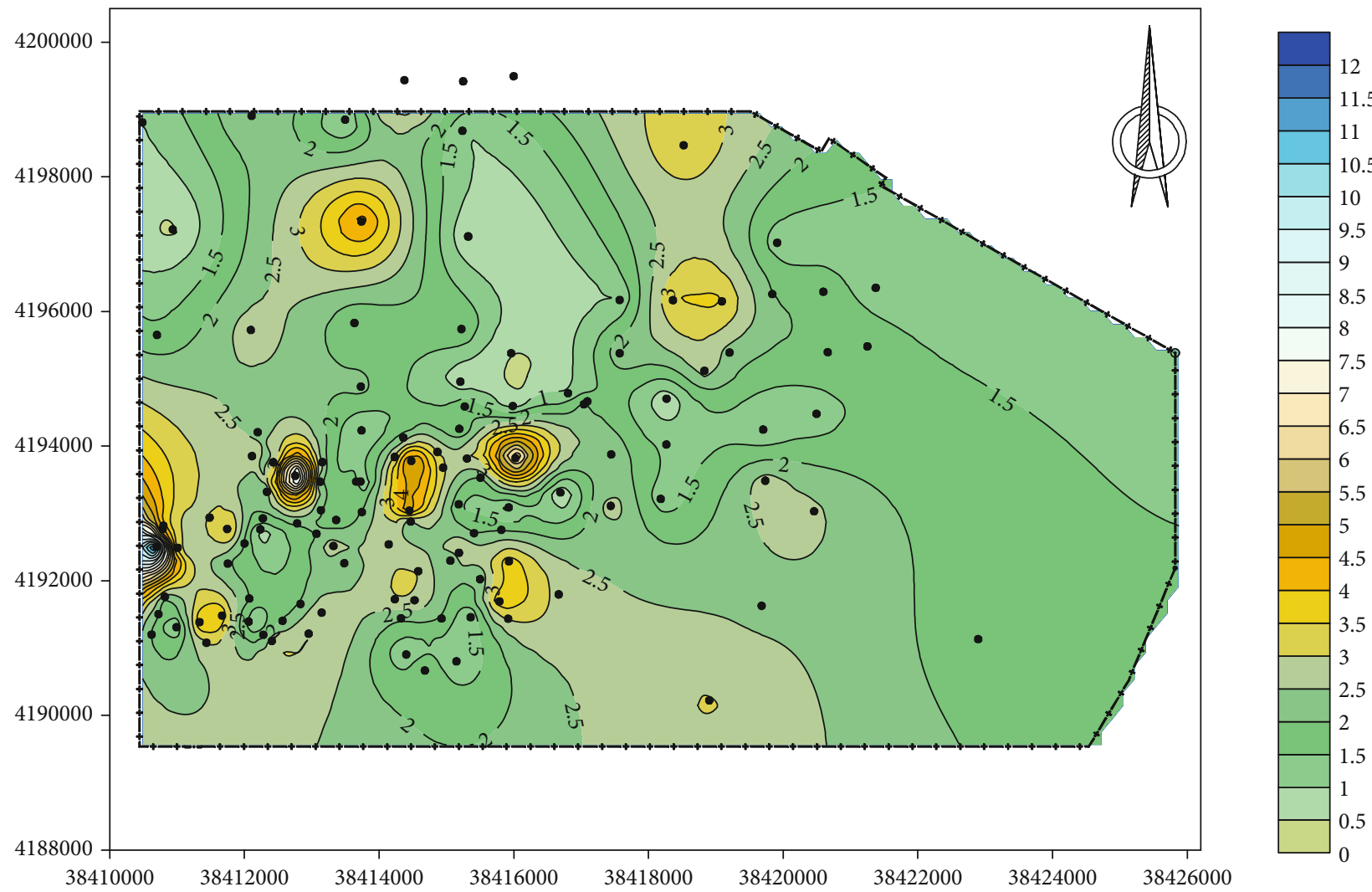

FIgURE 2: Thematic map of the $\mathrm{K}_{2}$ limestone isobaric line.

as shown in Figure 3. It can be seen from the thematic map of limestone floor buried depth that $\mathrm{K}_{2}$ limestone is buried deeper in the north than in the south. The maximum buried depth data is $890.31 \mathrm{~m}$. The thickness of limestone decreases from north to south, and the buried depth is mainly between $300 \mathrm{~m}$ and $500 \mathrm{~m}$.

\subsubsection{Thematic Map of Hydrogeological Characteristics}

(1) $K_{2}$ Limestone Water Level Thematic Map. According to drilling data, analyze the corresponding $\mathrm{K}_{2}$ limestone water level value and draw the contour map of $\mathrm{K}_{2}$ limestone initial water level, as shown in Figure 4 . It can be seen from the figure that the initial water level of $\mathrm{K}_{2}$ limestone is high in the middle, low in the northwest and southeast, and the water level in the southwest of the mine field is the highest.

(2) Thematic Map of Water Consumption of the $K_{2}$ Limestone Borehole. For the statistical data of coal seam drainage holes, mine hydrogeology holes, underground exploration holes, etc., study the water consumption data of $\mathrm{K}_{2}$ limestone drilling holes and draw a thematic map of $\mathrm{K}_{2}$ limestone drilling water consumption (as shown in Figure 5). The water con- sumption in the central part of the mining field is large, and the karst fissure development degree is high and the groundwater mobility is good. On the whole, the karst fissure development in this area is good, and the groundwater conduction is smooth.

\subsubsection{Structural Thematic Map}

(1) Thematic Map of Fault Fractal Dimension Value. The fractal dimension value of fault structure in the mining field is shown in Figure 6. According to the thematic map analysis of fault fractal dimension value, it can be seen that the fault fractal dimension value decreases from northeast to southwest. The fault fractal dimension value in the whole mining field is 1.35 at the maximum $(38417648.7005,4196650.361)$ and 0 at the minimum, so the fault does not develop in this area. Generally speaking, the fault development degree is high in the east and northeast of the mine field, but undeveloped in the west.

(2) Thematic Map of Fractal Dimension Value of the Collapse Column. The fractal dimension of the collapse column in the mining field is shown in Figure 7. By analyzing the thematic 


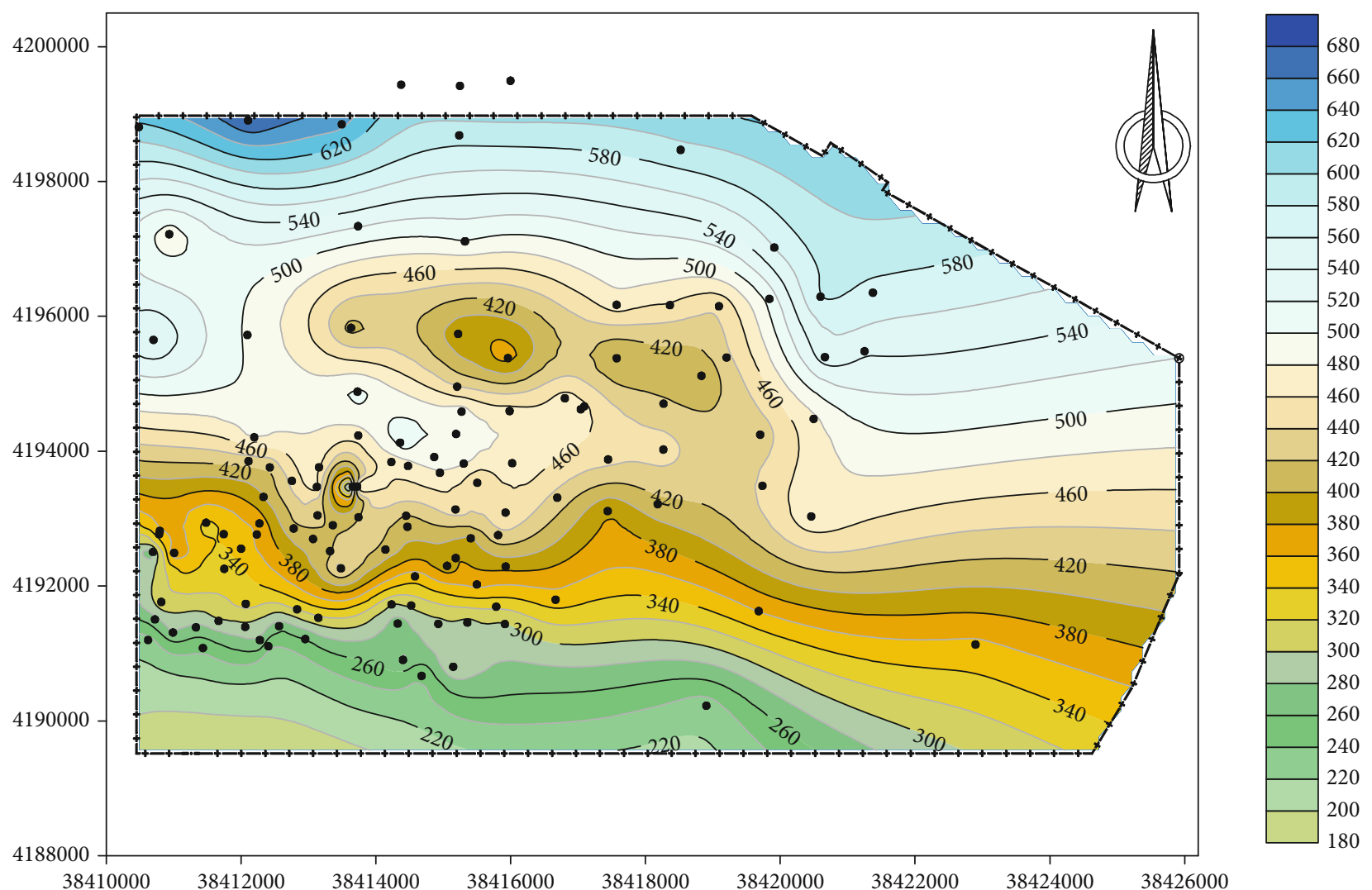

Figure 3: Thematic map of buried depth of the $\mathrm{K}_{2}$ limestone floor.

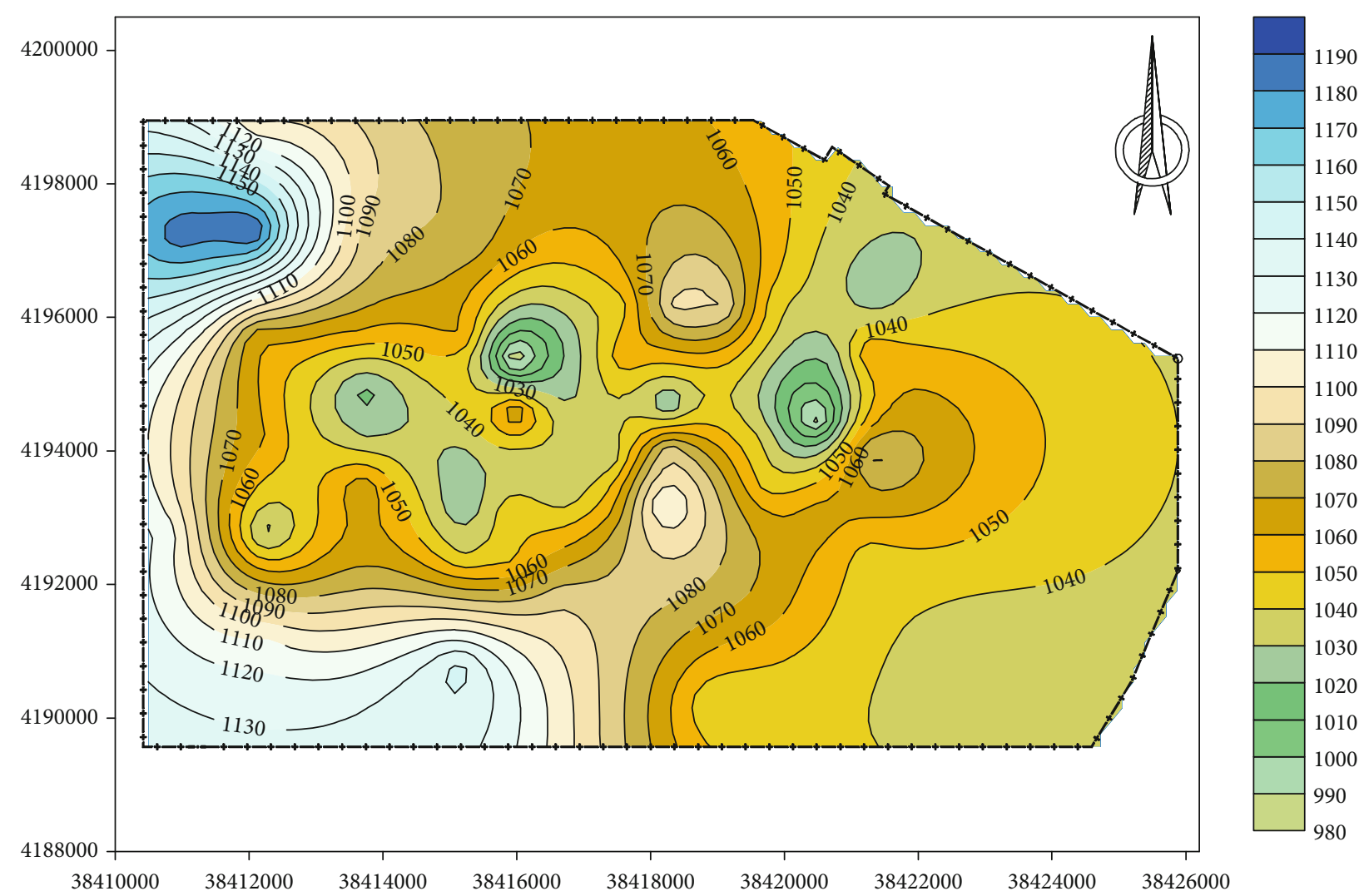

FIgURE 4: Thematic map of the initial water level of the $\mathrm{K}_{2}$ limestone aquifer. 


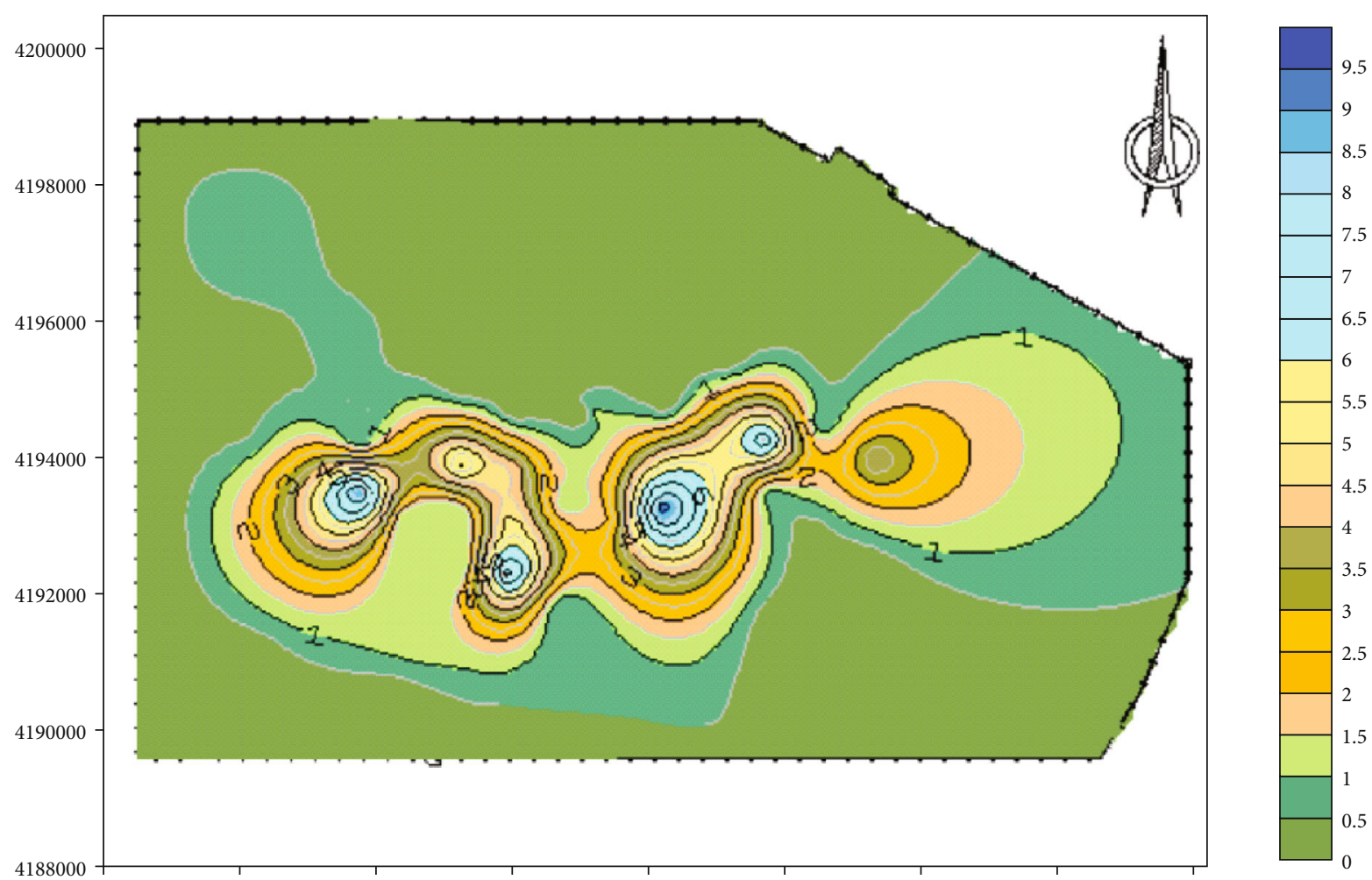

Figure 5: Thematic map of $\mathrm{K}_{2}$ limestone water consumption.

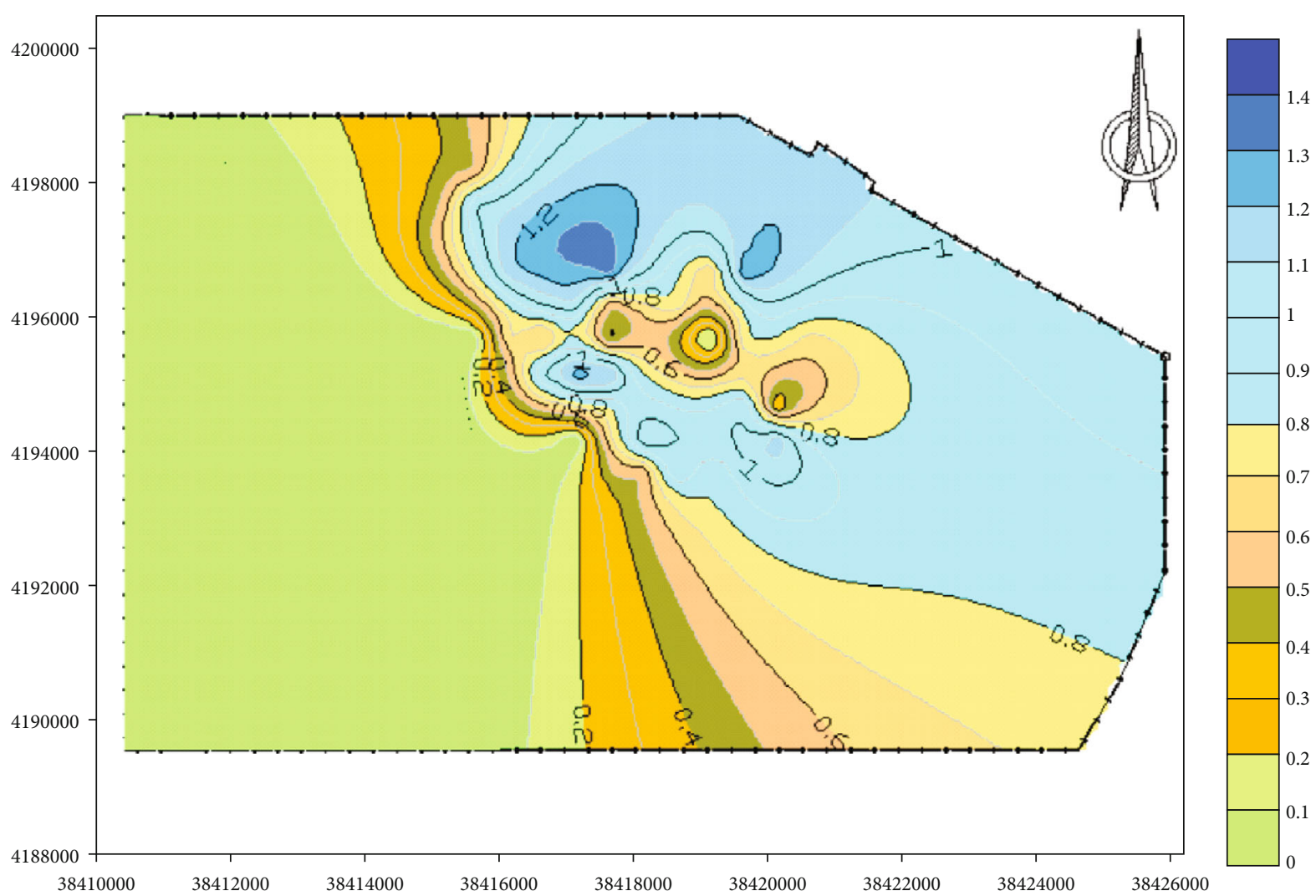

Figure 6: Thematic map of the fault fractal dimension value. 


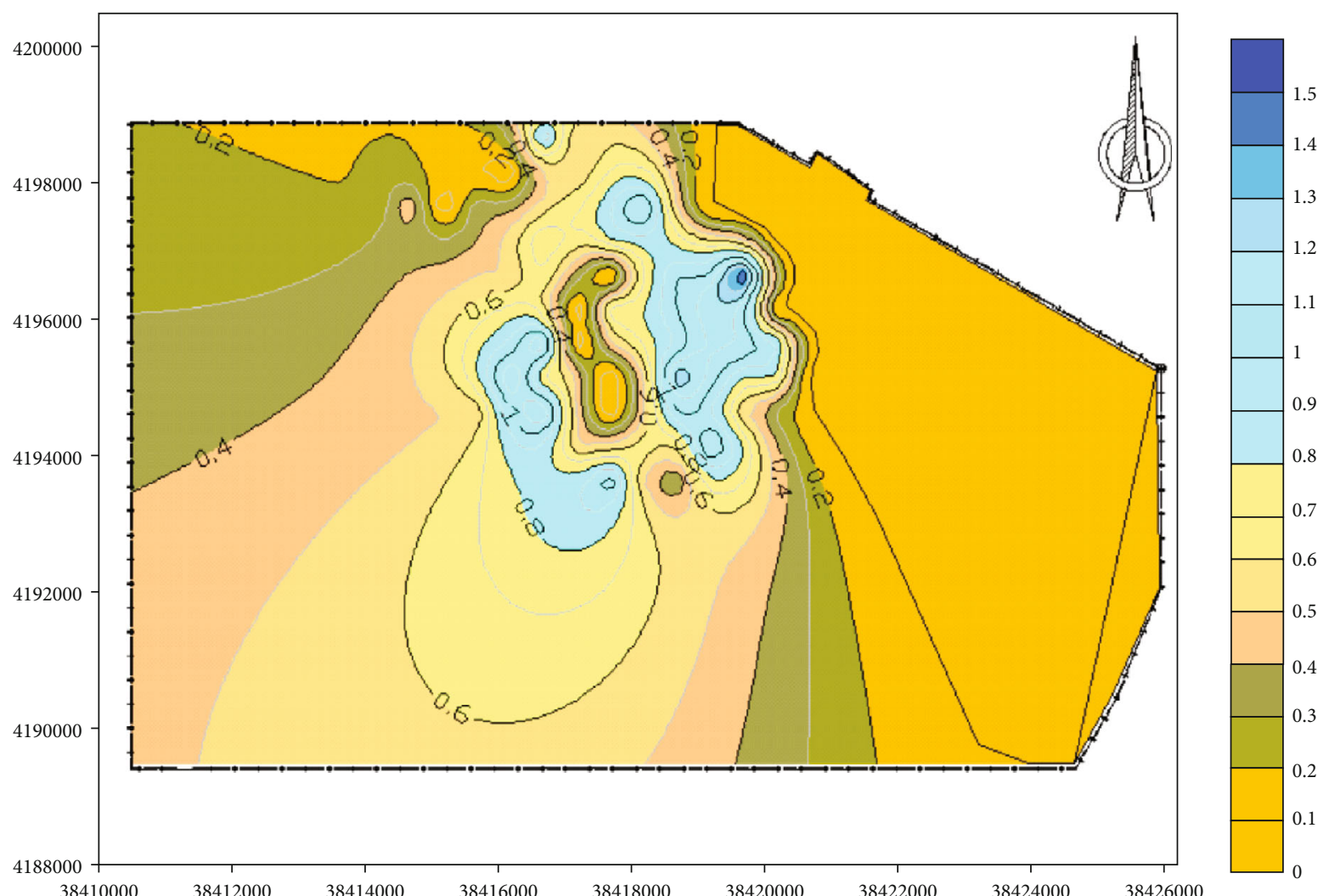

Figure 7: Thematic map of the fractal dimension value of the collapse column.

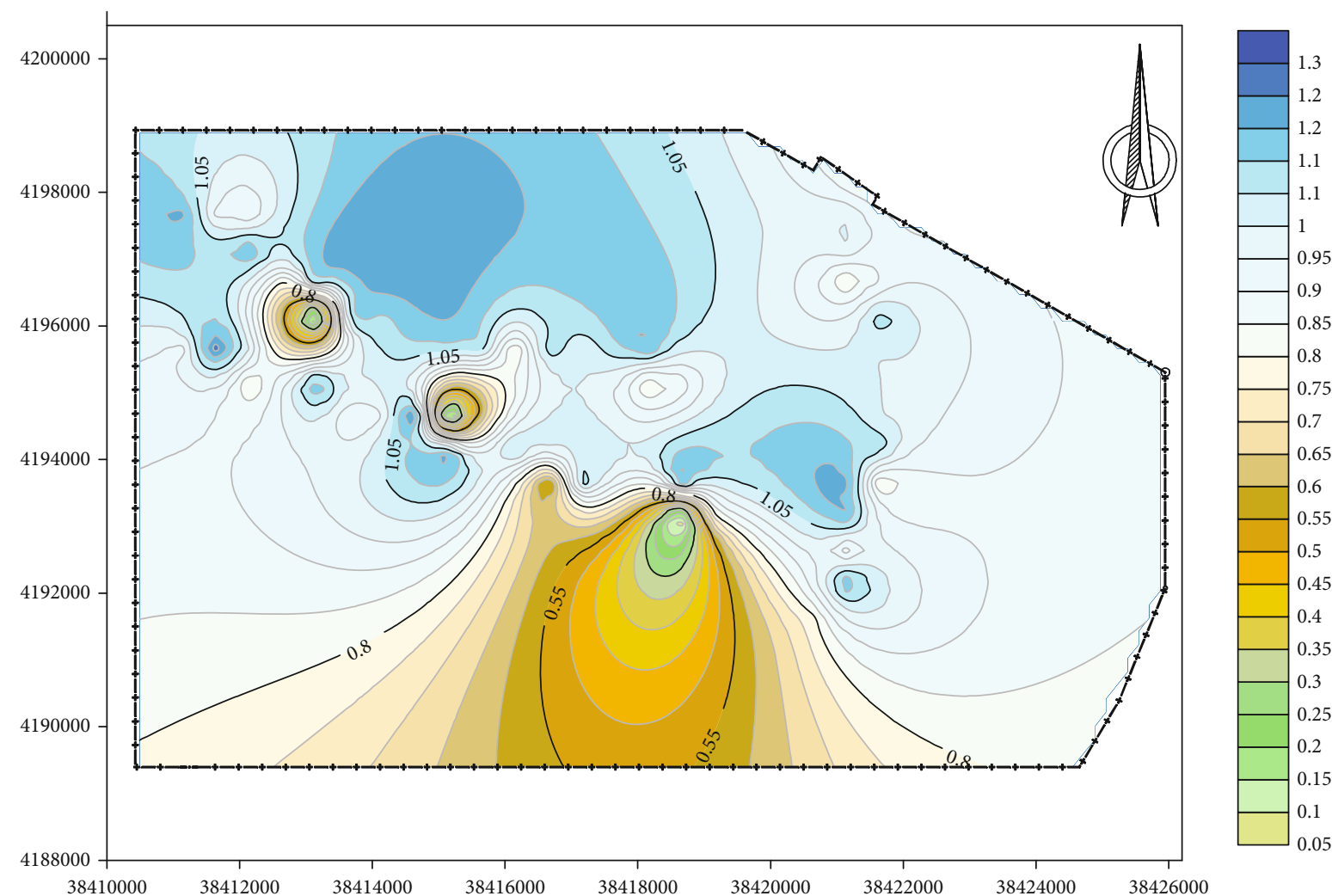

FIgURE 8: Thematic map of the fold fractal dimension value. 


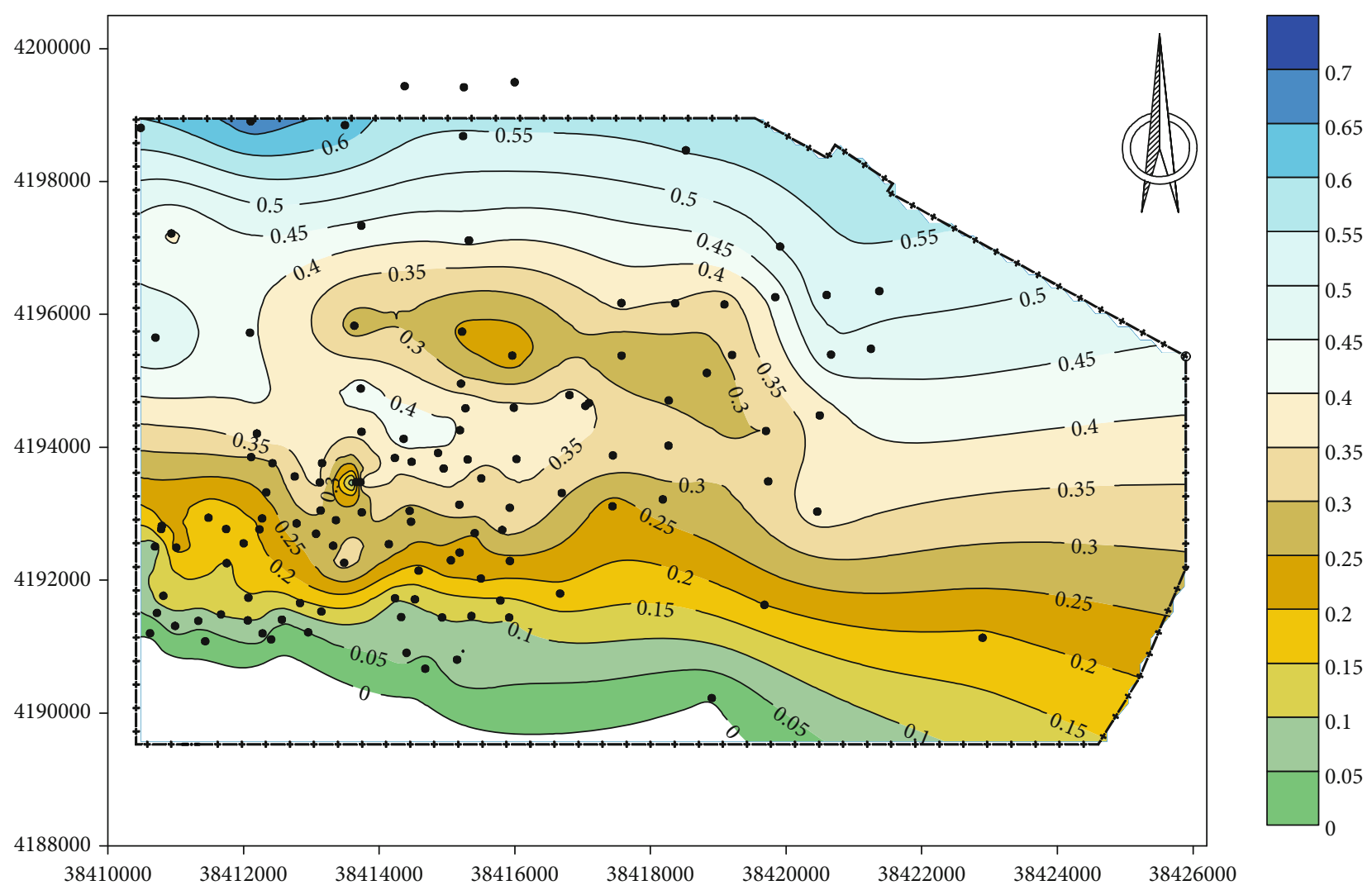

(a) Buried depth of $K_{2}$ limestone

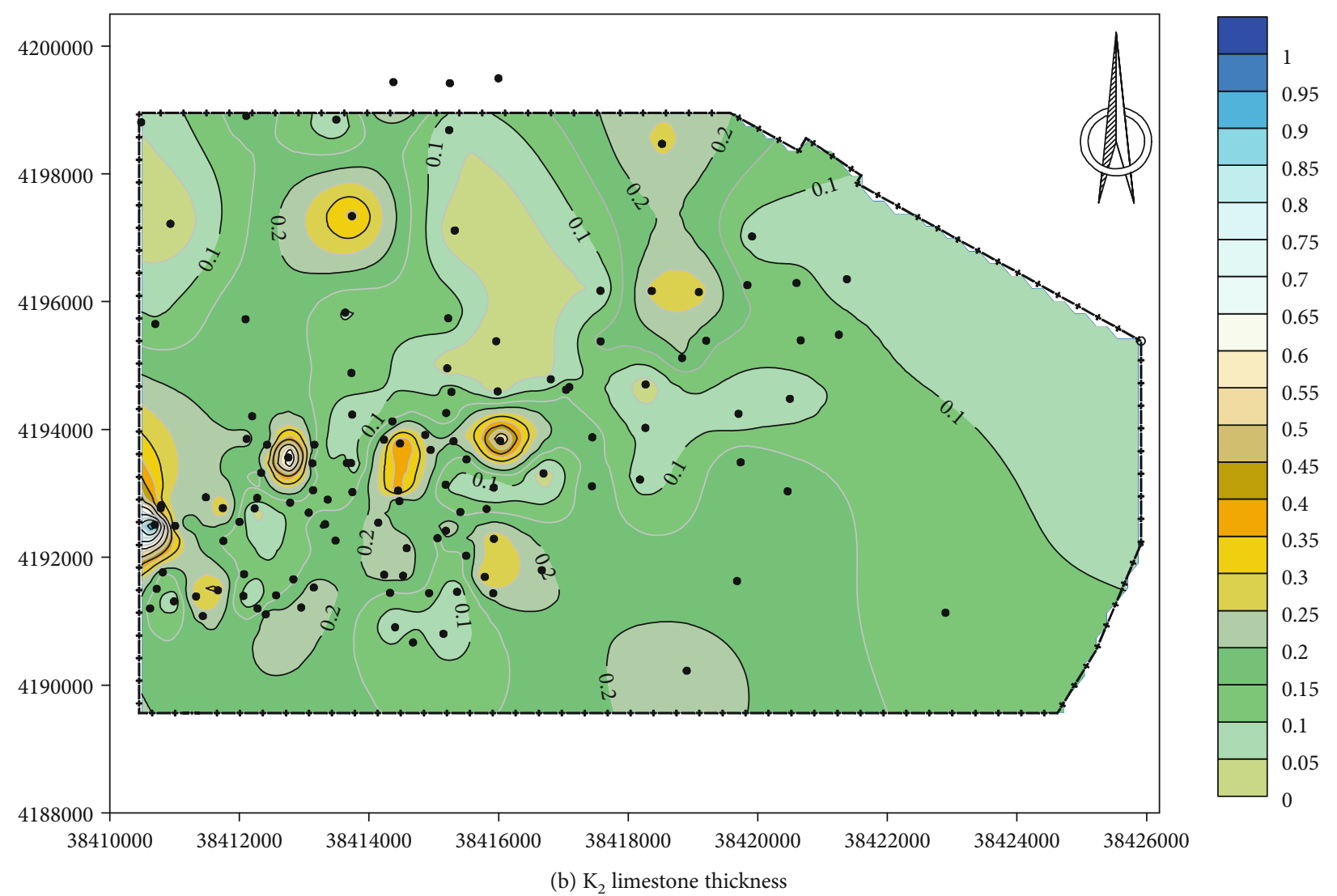

Figure 9: Continued. 

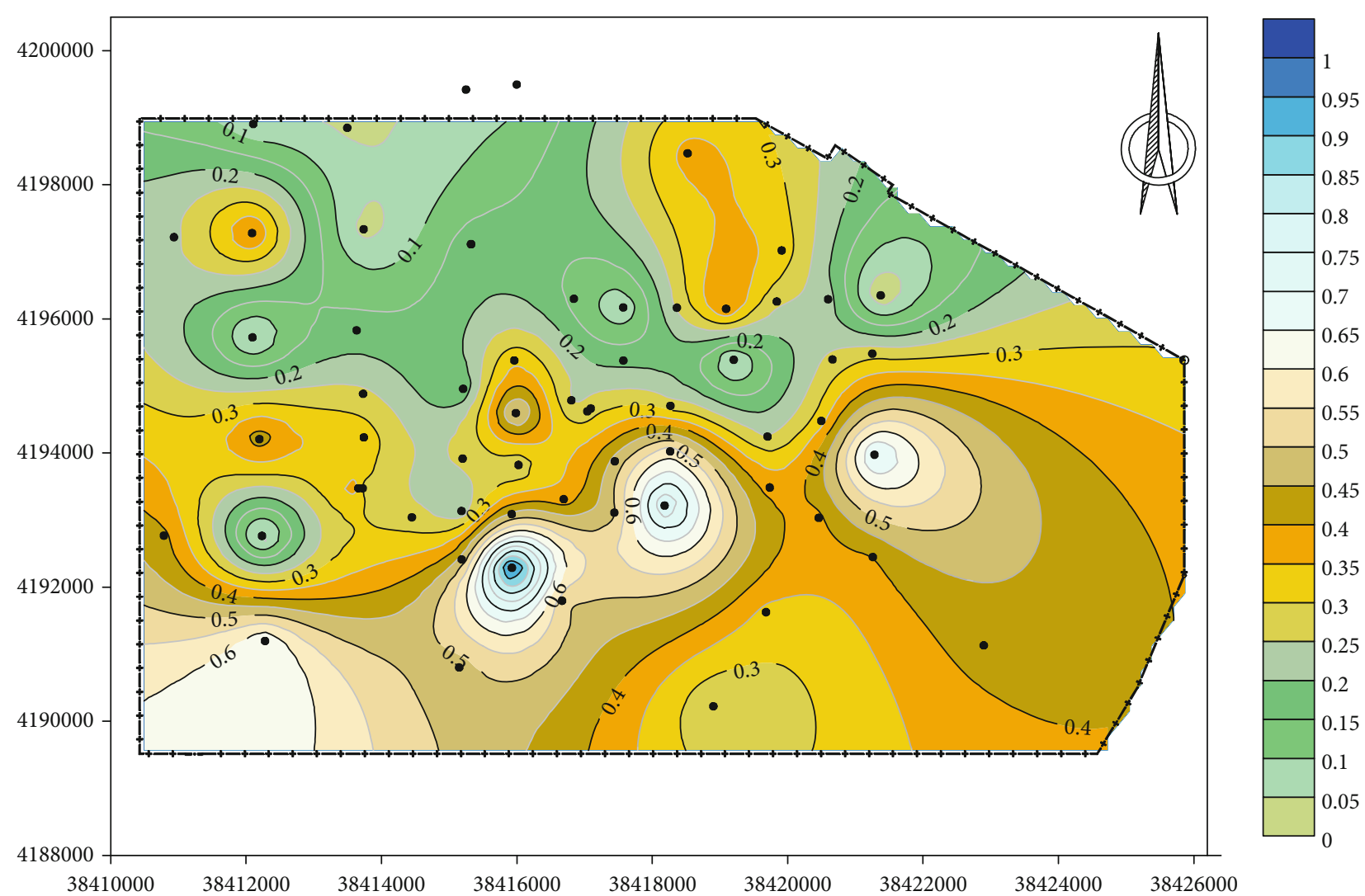

(c) Water level

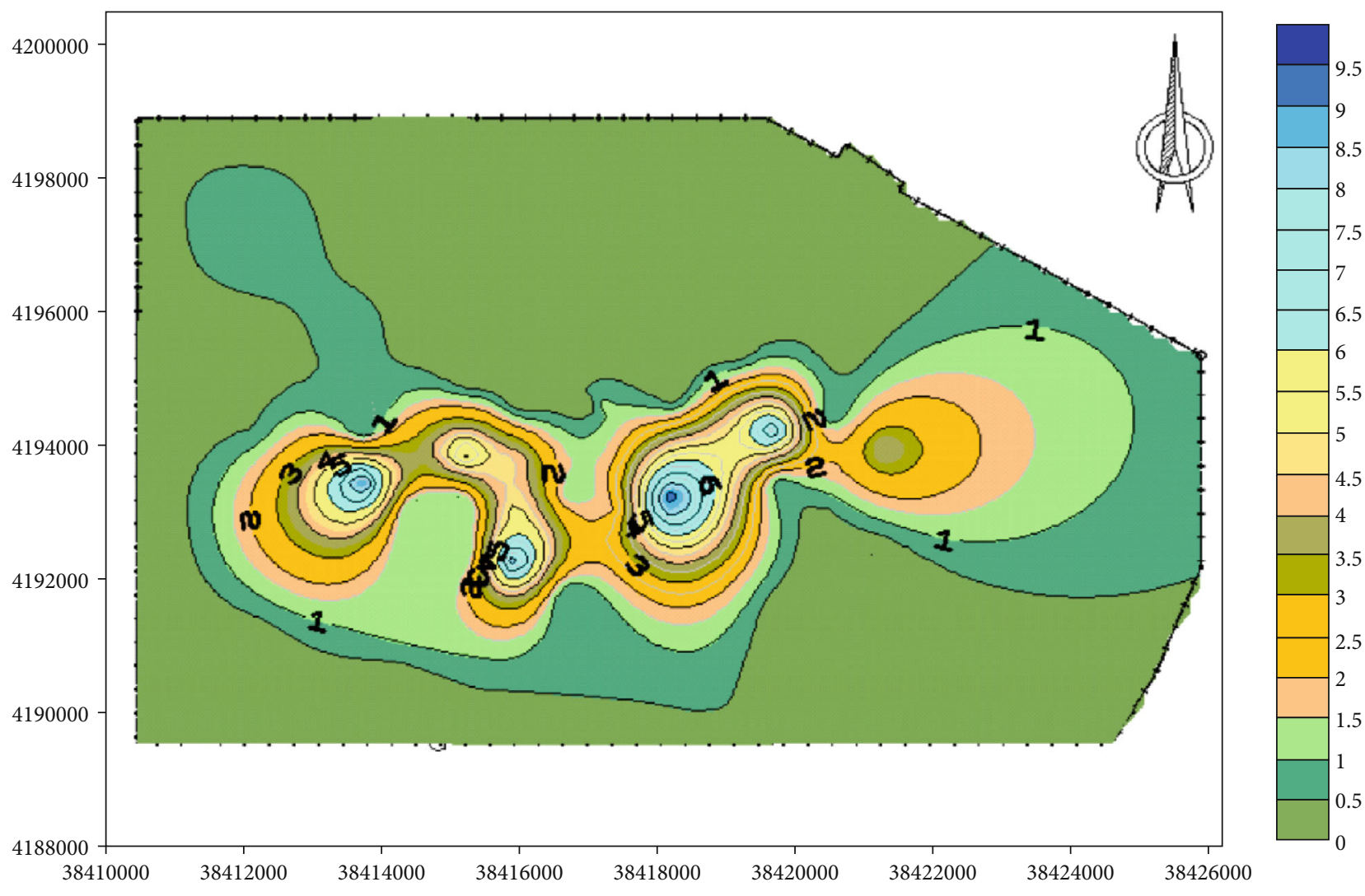

(d) Water consumption

Figure 9: Continued. 


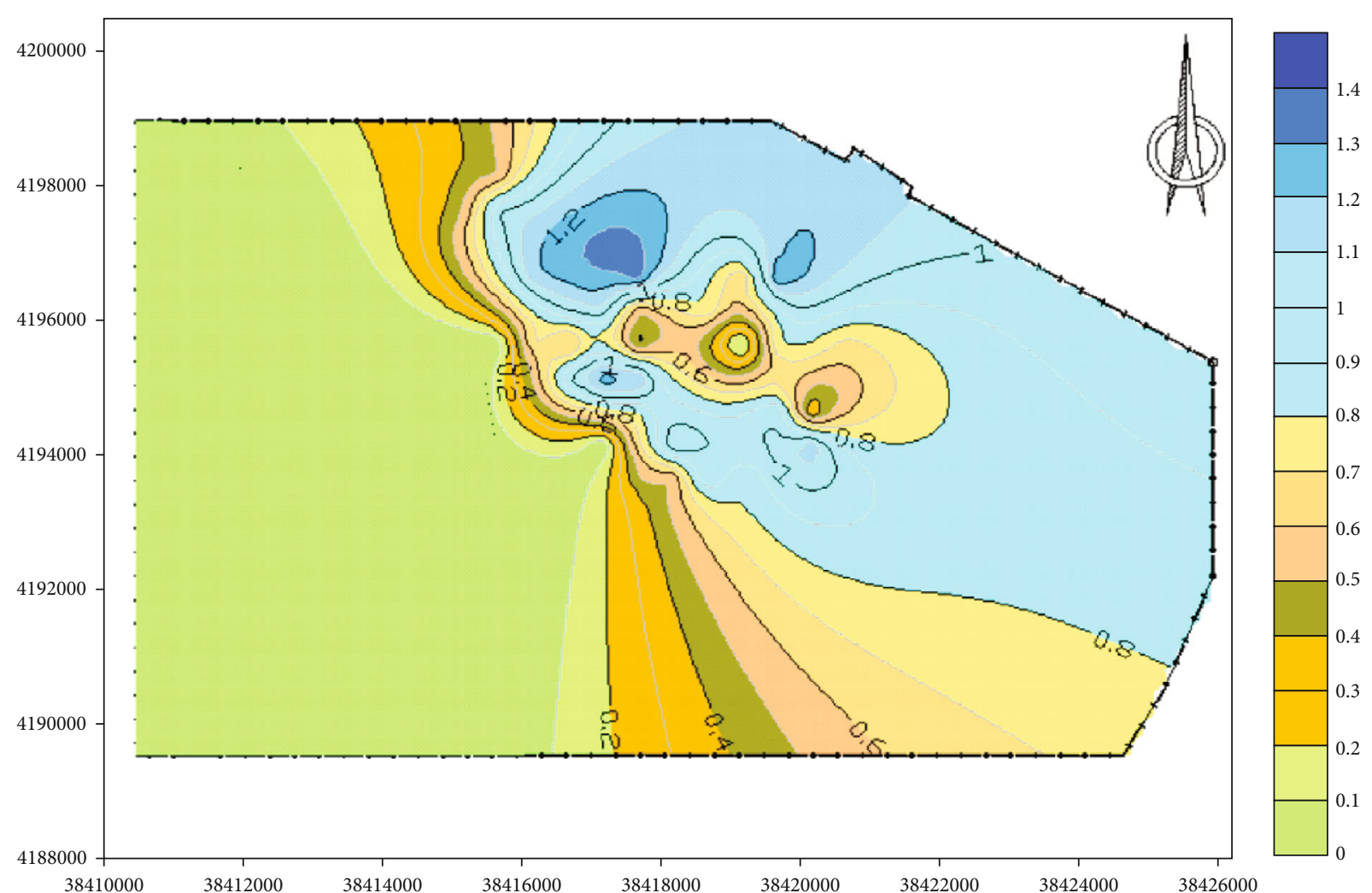

(e) Fault
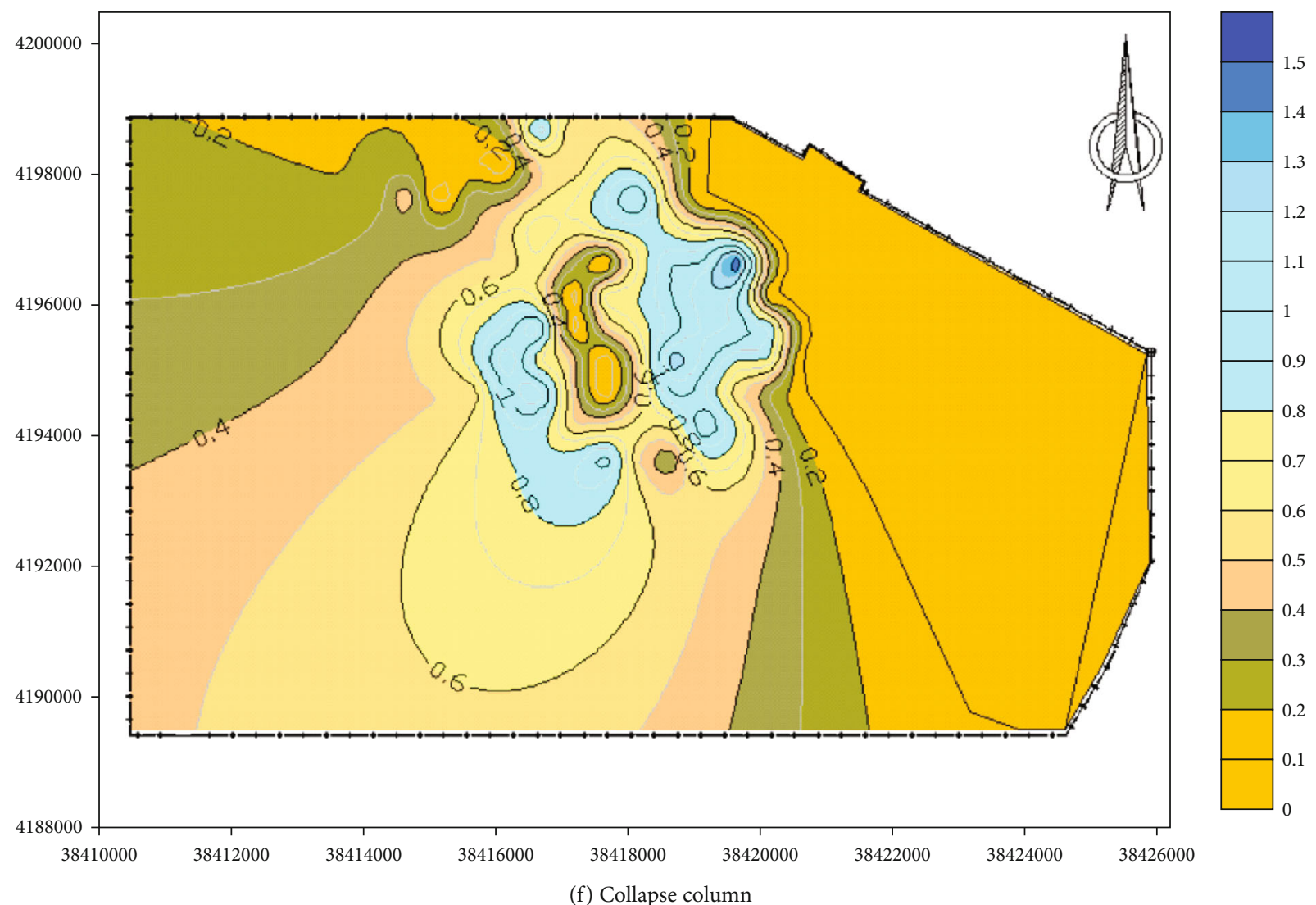

Figure 9: Continued. 


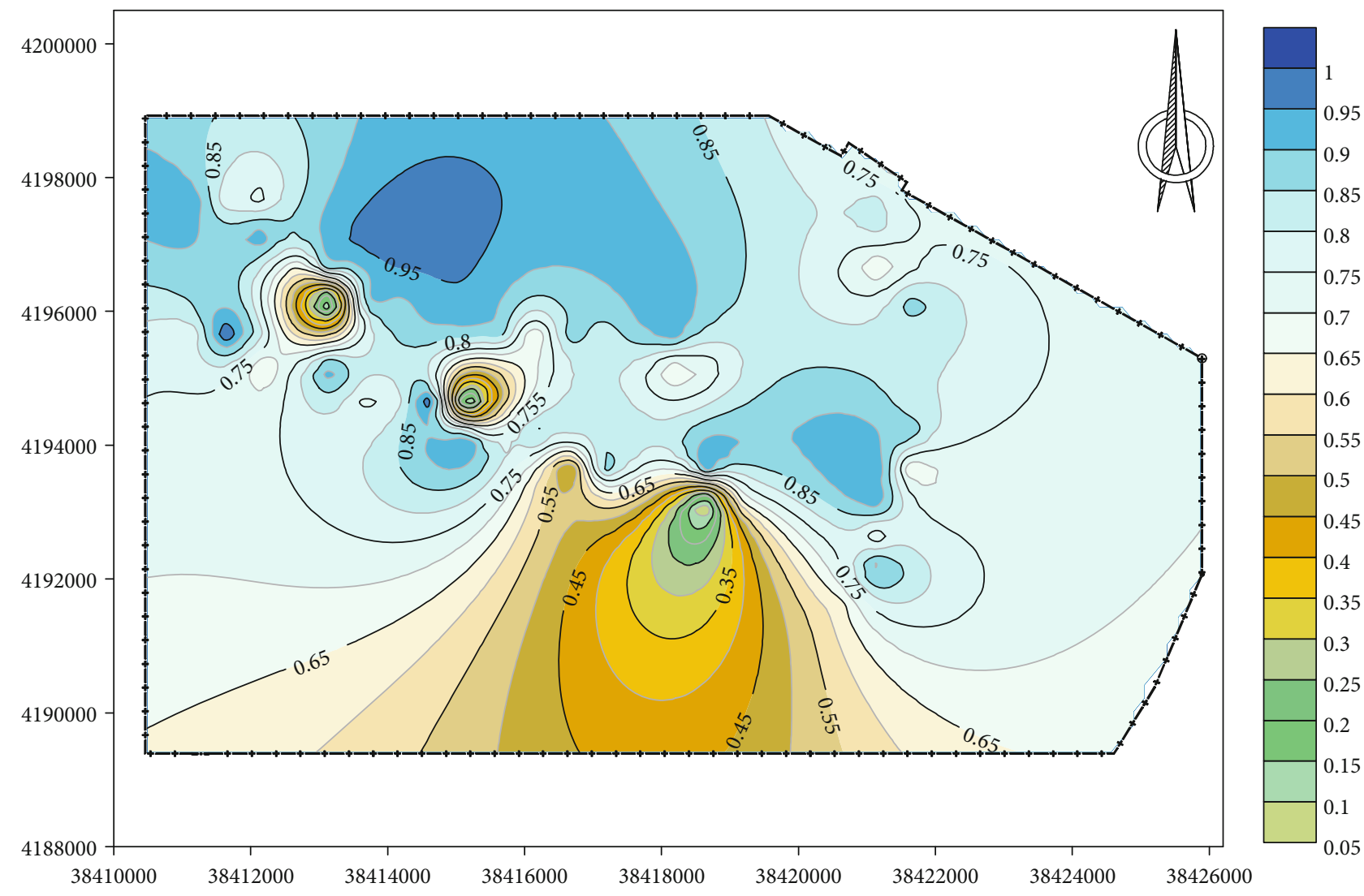

(g) Fold

FIGURE 9: Normalized thematic map of each single factor.

map of fractal dimension value of the collapse column, it can be seen that the maximum fractal dimension value of the collapse column is 1.585 and the minimum fractal dimension value is 0 . On the whole, the development degree of the collapse column is high in the middle of the mining field and low in the northeast.

(3) Thematic Map of Fold Fractal Dimension Value. The fractal dimension of fold in the mining field is shown in Figure 8. By analyzing the thematic map of fold fractal dimension, it can be seen that the fold development degree in the north of the mine field is higher than that in the south.

5.2. Establishment of the Normalized Thematic Map. The water richness index model of the coal seam roof aquifer is actually a mathematical model to express the comprehensive influence of various geological information. The calculation results of this model can reflect the water richness degree of the water-filled aquifer in a certain area. The establishment of the initial model must be based on various geological information to reflect the water richness of the aquifer. Because a single thematic map contains only one geoscience information, it cannot meet the requirements of multiinformation comprehensive processing through digital models. Therefore, an initial model must be built first, which can basically reflect the comprehensive effect of local learning information, and then, through repeated parameter adjust- ment and fitting operation, it can gradually approach the target, and finally a model that can reflect the actual situation of water richness of the aquifer in the coal seam roof is established. Therefore, in order to fuse geoscience information data, it is necessary to establish a normalized theme map of each factor.

5.2.1. Data Normalization. The evaluation adopts linear function transformation, and the expression is as follows:

$$
y_{i}=\frac{x_{i}-\operatorname{Min} x_{i}}{\operatorname{Max} x_{i}-\operatorname{Min} x_{i}}
$$

5.2.2. Single-Factor Normalized Thematic Map. After the single-factor data is normalized, each single-factor attribute database is established. Using the normalized data at the same borehole coordinate position, each single-factor normalized thematic map is made as shown in Figure 9.

5.3. Comprehensive Evaluation Chart of Water Richness. By constructing grid and drilling distribution coordinate position as shown in Figure 10, the encrypted normalized thematic map isoline is projected to read out the normalized thematic map values of each factor at the same position. According to the water richness evaluation model established above, the comprehensive evaluation of water richness is shown in Figure 11. It can be seen from the figure that the 


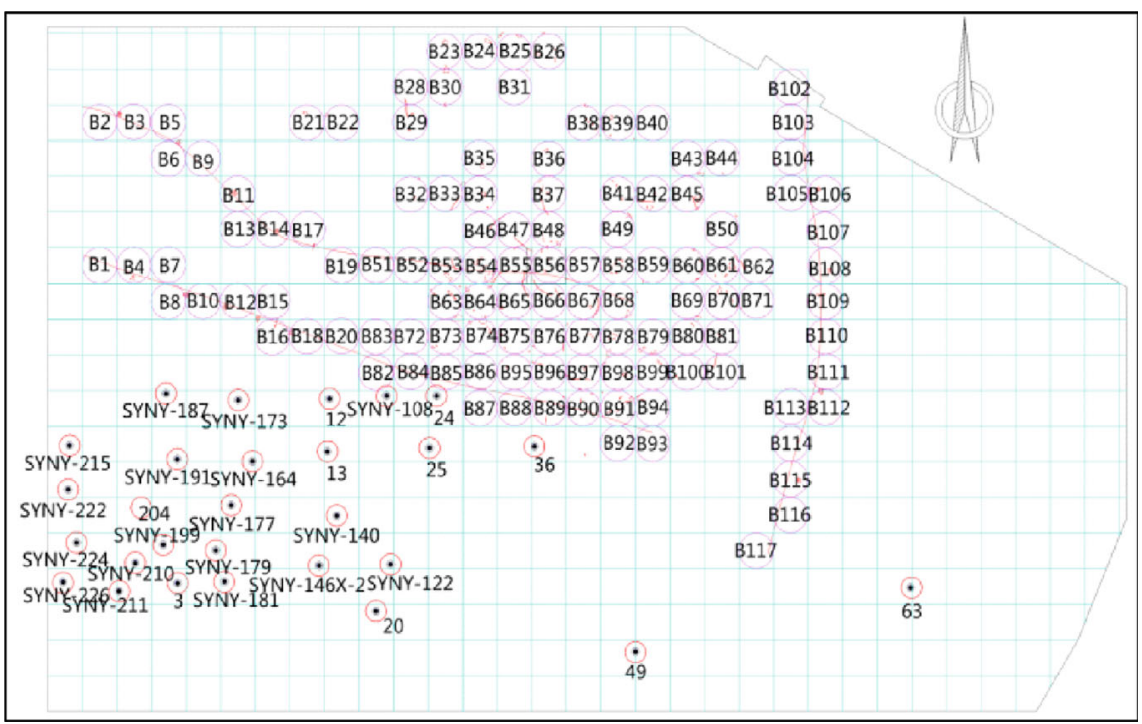

Figure 10: Structural grid and borehole distribution map.

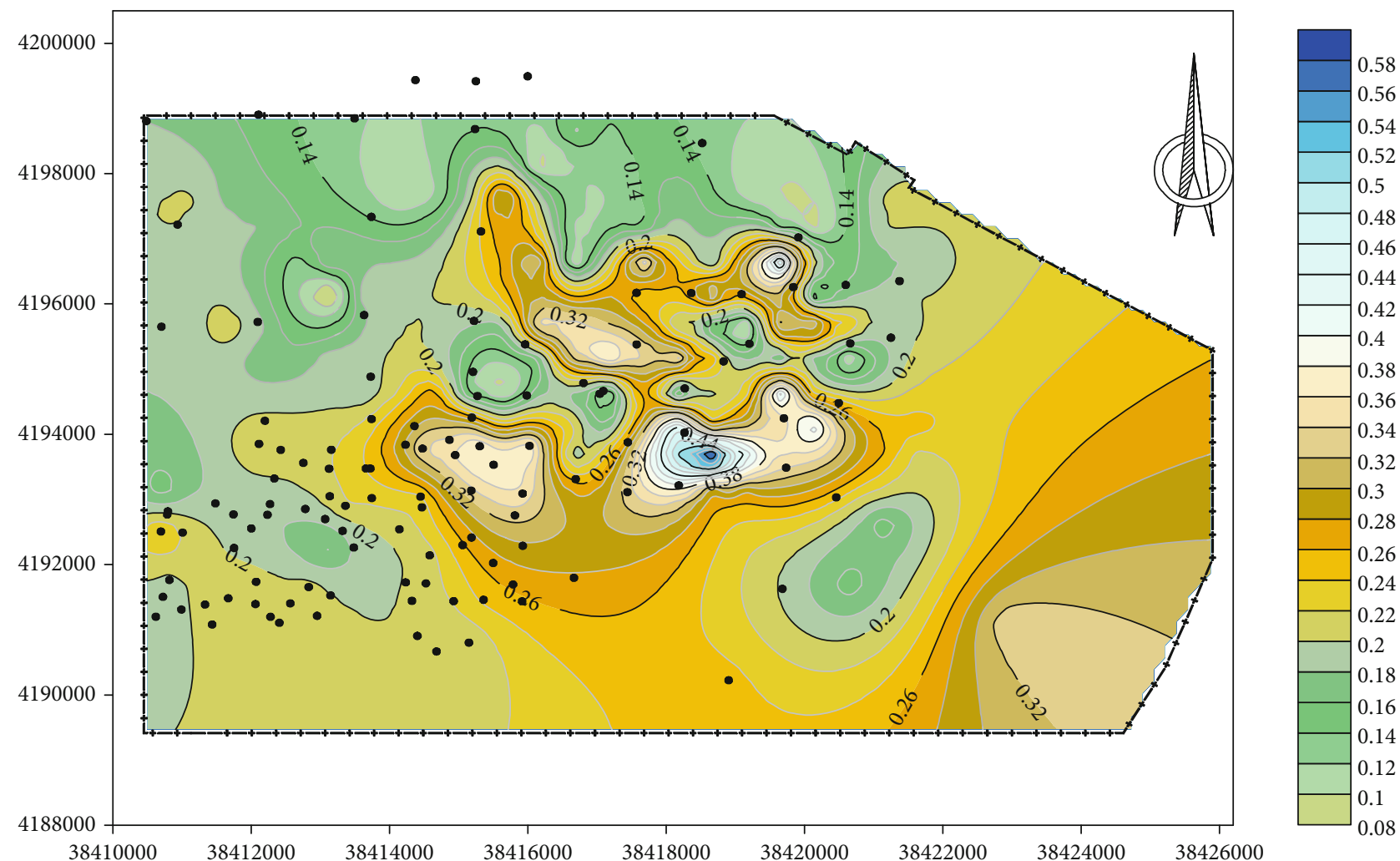

FIGURE 11: Multifactor superposition diagram of $\mathrm{K}_{2}$ limestone water richness.

water richness property in the northwest of the mining field is poor, while the water richness property in the middle and northeast is good, especially in the middle.

5.4. Water Richness Zoning Map. Through the mathematical statistical analysis of the spatial data of the influence degree of water richness, combined with the water inflow data related to $\mathrm{K}_{2}$ limestone drilling in the past, water richness indexes of $0.12,0.2$, and 0.3 are the basis of division. According to the water richness index, the whole area is divided into four areas with different relative water richness degrees, and the water richness areas are in order from large to small: weak water richness areas, medium water richness areas, strong water richness areas, and extremely strong water richness areas. See Figure 12 for the water richness zoning map of $\mathrm{K}_{2}$ limestone. It can be seen from the figure that the water 


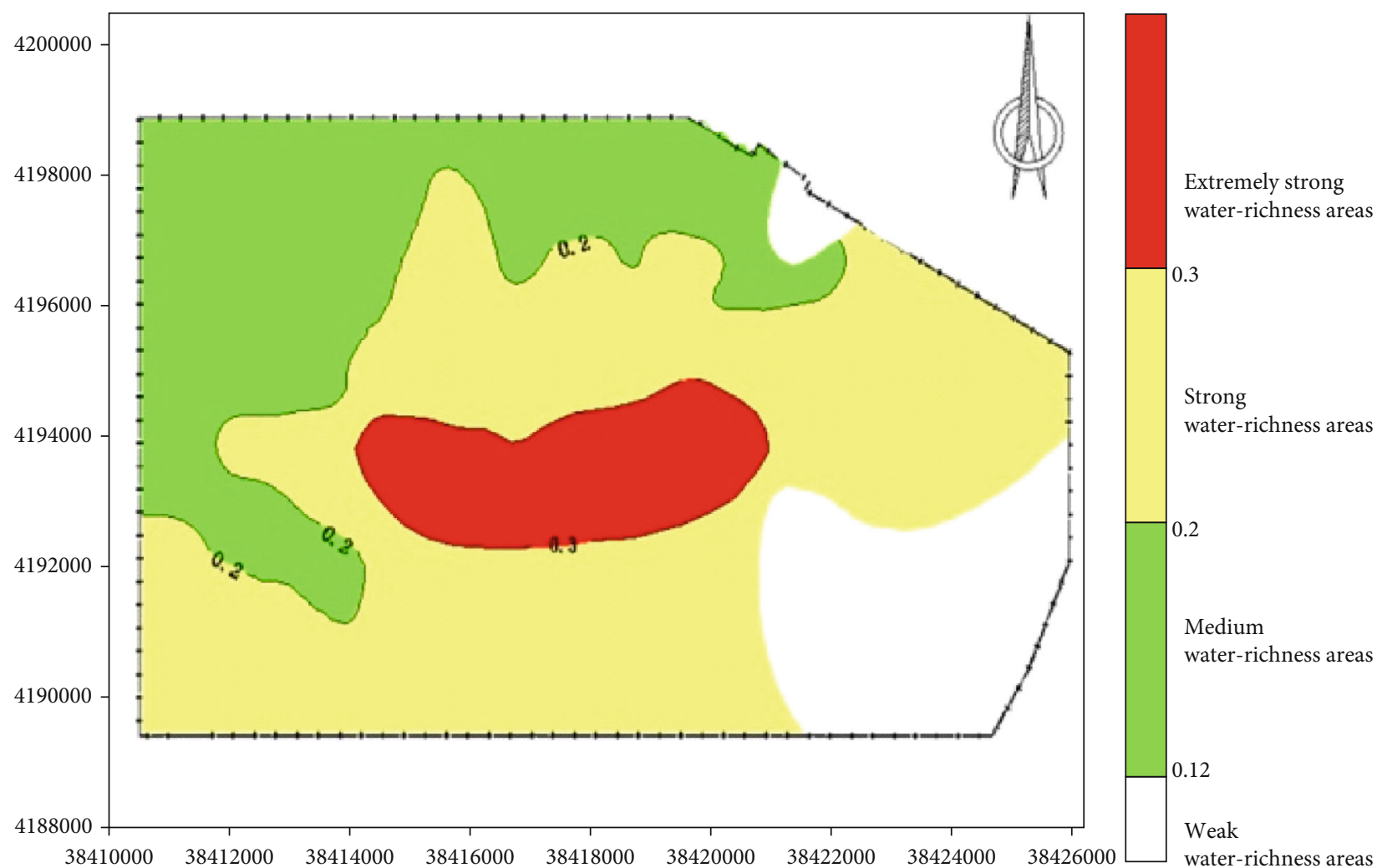

FIGURE 12: Water richness zoning map of the $\mathrm{K}_{2}$ limestone aquifer.

richness property in the middle, southeast, and central part of the mine field is strong extremely strong, which is the focus of mine water disaster prevention and control work.

(1) $0.3<\mathrm{CI}$ : extremely strong water richness areas

(2) $0.2<\mathrm{CI} \leq 0.3$ : strong water richness areas

(3) $0.12<\mathrm{CI} \leq 0.2$ : medium water richness areas

(4) $0<\mathrm{CI} \leq 0.12$ : weak water richness areas

\section{Conclusions}

(1) Based on the factors affecting karst development and combined with the specific conditions of the study area, three main control factors are determined, including aquifer characteristics, hydrogeological characteristics, and structural characteristics, and seven water richness evaluation indexes are divided, namely, $\mathrm{K}_{2}$ limestone buried depth, $\mathrm{K}_{2}$ limestone aquifer thickness, borehole water level, borehole water consumption, faults, folds, and collapse columns

(2) The weight of seven independent influencing factors is assigned by AHP, and the water richness evaluation model of the normalized $\mathrm{K}_{2}$ limestone aquifer is constructed

(3) The geoinformation thematic map of each independent factor is established, and on this basis, the com- prehensive evaluation map of water richness is established

(4) The water richness evaluation results show that the water richness property in northwest of the mine field is poor, while the water richness property in the middle and northeast of the mine field is better, especially in the middle part. It provides scientific guidance for mine water disaster prevention and control

\section{Data Availability}

The data used to support the findings of this study are available from the corresponding author upon request.

\section{Conflicts of Interest}

The author declares that there is no conflict of interest regarding the publication of this paper.

\section{References}

[1] Q. Wu, F. P. Cui, and S. Q. Zhao, "Type classification and main characteristics of mine water disasters," Journal of China Coal Society, vol. 38, no. 4, pp. 561-565, 2013.

[2] W. Y. Hu and G. Tian, "Mine water disaster type and prevention and control countermeasures in China," Coal Science and Technology, vol. 38, no. 1, pp. 92-96, 2010. 
[3] Q. Wu, "Progress, problems and prospects of prevention and control technology of mine water and reutilization in China," Journal of China Coal Society, vol. 39, no. 5, pp. 795-805, 2014.

[4] G. Q. Liu, X. L. Yu, and F. H. Li, "Expert system of mine roof flood forecast and its prevention and control," The Chinese Journal of Geological Hazard and Control, vol. 12, no. 1, pp. 71-74, 2001.

[5] State Administration of Work Safety, State Administration of Coal Mine Safety, Coal mine water control regulations, Beijing: Coal Industry Press, 2009.

[6] Q. Wu, X. L. Huang, and D. L. Dong, "Three maps two predictions method to evaluate water bursting conditions on roof coal," Journal of China Coal Society, vol. 25, no. 1, pp. 60-65, 2000.

[7] H. R. Zhang, R. F. Zhou, and D. Z. Guo, "Investigation on predicting roof water gush in coal mines based on multi-factor analysis," Journal of China University of Mining \& Technology, vol. 34, no. 1, pp. 112-116, 2005.

[8] C. Han, X. H. Pan, and G. L. Li, "The fuzzy analytic hierarchy process of water abundance of an aquifer based on GIS and multi-source information fusion techniques," Hydrogeology \& Engineering Geology, vol. 39, no. 4, pp. 19-25, 2012.

[9] Q. Wu, K. Xu, and W. Zhang, "Further research on "three maps-two predictions" method for prediction on coal seam roof water bursting risk," Journal of China Coal Society, vol. 41, no. 6, pp. 1341-1347, 2016.

[10] S. Q. L. Fan, "Water-richness evaluation method of waterfilled aquifer based on the principle of information fusion with GIS: water-richness index method," Journal of China Coal Society, vol. 36, no. 7, pp. 1124-1128, 2011.

[11] Y. F. Zeng, Q. Wu, and X. Du, "Further research on "waterrichness index method" for evaluation of aquifer water abundance," Journal of China Coal Society, vol. 45, no. 7, pp. 2423-2431, 2020.

[12] Y. G. Lv, H. J. Li, and Y. J. Xia, "Prediction and evaluation study on coal seam roof water inrush based on multi-type four-double method," Coal Science and Technology, vol. 47, no. 9, pp. 219-228, 2019.

[13] Q. L. Bu, C. X. Chen, and C. C. Yang, "Zoning index of rich water-bearing roof strata and water inrush forecasting in coal seams," Journal of Shandong University of Science and Techno$\operatorname{logy}$ (Natural Science), vol. 24, no. 3, pp. 28-31, 2005.

[14] M. Qiu, L. Q. Shi, and C. Teng, "Water-richness evaluation of Ordovician limestone based on grey correlation analysis, FDAHP and geophysical exploration," Chinese Journal of Rock Mechanics and Engineering, vol. 35, no. S1, pp. 3203-3213, 2016.

[15] C. H. Han, J. C. Wei, and D. L. Xie, "Water-richness evaluation of sandstone aquifer based on set pair analysis variable fuzzy set coupling method: a case from Jurassic Zhiluo formation of Jinjiaqu coal mine in Ningdong mining area," Journal of China Coal Society, vol. 45, no. 7, pp. 2432-2443, 2020.

[16] E. K. Hou, R. J. Tong, and S. J. Wang, "Prediction method for the water enrichment of weathered bedrock based on Fisher model in northern Shaaxi Jurassic coalfield," Journal of China Coal Society, vol. 41, no. 9, pp. 2312-2318, 2016.

[17] J. C. Wei, Y. Y. Xu, and D. L. Xie, "Risk assessment of water inrush based on distance function combination weighting method," China Mining Industry, vol. 30, no. 4, pp. 162-167, 2021.
[18] J. K. Xue, "Application of water-rich index method based on fractal theory in aquifer water-rich evaluation," Coal Mine Safety, vol. 51, no. 2, pp. 197-201, 2020.

[19] Q. C. Guo, W. P. Li, and T. G. Guo, "Evaluation of phreatic water abundance in weathered zone covered by aeolian sand based on FAHP-GRA method," Coal Mine Safety, vol. 49, no. 12, pp. 35-40, 2018.

[20] P. Grassberger, "On efficient box counting algorithms," International Journal of Modern Physics, vol. 4, no. 3, pp. 515523, 1983.

[21] Q. Wu, S. Fan, W. Zhou, and S. Liu, "Application of the analytic hierarchy process to assessment of water inrush: a case study for the no.17 coal seam in the Sanhejian coal mine, China," Mine Water and the Environment, vol. 32, no. 3, pp. 229-238, 2013.

[22] Q. X. Wang, H. Wang, and Z. Q. Qi, “An application of nonlinear fuzzy analytic hierarchy process in safety evaluation of coal mine," Safety Science, vol. 86, pp. 78-87, 2016.

[23] X. Deng, J. M. Li, and H. J. Zeng, "Analysis and application of weight calculation method of analytic hierarchy process," Mathematics in Practice and Theory, vol. 42, no. 7, pp. 93100, 2012.

[24] SAATY T L, The Analytic Hierarchy Process, McGraw-Hill, NYC, 1980. 